\title{
Evidence Struggles: Legality, Legitimacy, and Social Mobilizations in the Catalan Political Conflict
}

\author{
SUSANA NAROTZKY, UNIVERSITAT DE BARCELONA*
}

\begin{abstract}
Different kinds of evidence are put forward to make an argument and justify political action by agents situated in diverse social, cultural, and power positions. The Catalan political conflict is a case in point. The central Spanish government's arguments are mostly of a juridical nature and rest on the anti-constitutionality of the Catalan government and other civil society organizations' actions. Instead, most arguments of Catalan supporters of independence are based on historical interpretations of grievances referring to national institutions and identity. Supporters of independence, under the politically inspired actions of major civil society associations, have mobilized hundreds of thousands of Catalans in massive demonstrations and have used media in a very efficient manner. The judicial responses to the secessionist process have used legality (police, prison) to allow repression, while the repeated anti-constitutional actions of the Catalan government have been justified as legitimated by popular support and by a historical accumulation of grievances.

At the same time, repeated elections show that Catalan citizens are divided and have very different positions regarding their support for independence. This differentiation can be mapped according to social and economic criteria and almost literally projected in spatial coordinates. This other group of Catalans tried to mobilize to publicly show their disagreement over the secessionist project. Yet their arguments appear as reactive rather than based on any alternative evidence. Hence, they are co-opted by the central Spanish various
\end{abstract}

\footnotetext{
* Acknowledgements: Research has been funded by the European Research Council Advanced Grant "Grassroots Economics: Meaning, Project and practice in the pursuit of livelihood" [GRECO], IDEAS-ERC FP7, Project Number: 323743. This contribution was prepared for the Indiana Journal of Global Legal Studies 26th Annual Symposium "Globalization in Question: Populist Resistance and a New Politics of Law?" Indiana University Maurer School of Law-Bloomington, April 12-13, 2018. I want to thank all the participants to the symposium and especially Professor Fred Aman for his kind invitation.
}

Indiana Journal of Global Legal Studies Vol. 26 \#1 (Winter 2019)

(C) Indiana University Maurer School of Law 
governments' juridical position, which supports a unified Spanish national identity couched in the Constitution of 1978.

This paper argues that an important aspect of the political confrontation is being played as an evidence struggle where the various social actors produce different kinds of evidence to justify their actions in the political arena and mobilize support.

Keywords: Catalan independence, symbolic evidence, legality, legitimacy, nationalism

\section{EVIDENCE STRUGGLES, AN INTRODUCTION}

The ongoing Catalan political conflict is historically deep and has many iterations. ${ }^{1}$ The present one is occurring in the context of a general rise of nationalist mobilizations in Europe following austerity policies implemented by neoliberal regimes, especially after the 2008 crisis. At the turn of the century, Spain saw the conservative Popular Party (PP) win an absolute majority in the national Parliament. ${ }^{2}$ This event triggered a tacit end to the multiparty agreement of the Transition period (1975-1982) that had enabled the establishment of democracy and the rule of law under the 1978 Constitution, after the death of Franco. As a result of increased deregulation of land use and sub-prime credit from 1996, a housing bubble expanded and peaked, only to burst in 2008. A banking crisis followed, and Spanish banks had to be bailed out by the European Central Bank, subject to strict conditions: restraining public deficit (austerity) and deregulating the labor market (internal devaluation). After 2000, central governments (especially PP governments) in a movement of relative political recentralization challenged the structure of the state as described in the 1978 Constitution which instituted the devolution of power to autonomous regions. This process became extremely aggressive after 2012 when the conservative party regained power after two terms of social democrat government. ${ }^{3}$ One of the areas picked out for re-

1. In this piece I limit the timeframe of the analysis to the events that occurred from September 2017 to May 2018. The juridical, political, and symbolic conflict is ongoing.

2. The Popular Party had won a majority in 1996, but because it did not have an absolute majority of seats, it was forced to manage other regional right wing parties-in particular the Catalan nationalist Convergència i Unió and the Basque nationalist Partido Nacionalista Vasco. In this conjuncture, the neoliberal interests overpowered Spanish nationalist interests, while regional nationalist elites leveraged their Parliamentary votes to earn some privileges.

3. The social democrat party PSOE had been in government for two election periods from 2004 to 2012. The second social democratic government of President Rodríguez Zapatero was to impose the first austerity measures, including a very controversial 
centralization was education, a particularly sensitive domain for Catalonia's autonomous language immersion system. ${ }^{4}$ Starting in 2010, the conflict of the nationalist Catalan and Spanish governments has acquired momentum and developed into a full-fledged institutional crisis.

In the struggle, agents situated in diverse social, cultural, and power positions use different kinds of evidence to make an argument and justify political action. The central Spanish government's arguments are mostly of a juridical nature and rest on the alleged anticonstitutionality of the actions of members of the Catalan government and two civil society organizations (Òmnium, Assamblea Nacional Catalana). Instead, the Catalan supporters of independence rest their arguments on historical grievances referring to national institutions, fiscal inequity, and identity. Independence supporters, under the politically inspired actions of major civil society associations, have mobilized hundreds of thousands of Catalans in massive demonstrations, and have used media in a very efficient manner. The judicial responses to the secessionist process have used legality to allow repression (police violence on October, 1, 2017), while the Catalan government has justified repeated anti-constitutional actions as legitimated by "popular will," and by the historical accumulation of grievances that the "Catalan people" hold against the central state.

At the same time, repeated elections show that Catalan citizens are divided and have very different positions regarding support for independence. This differentiation relates to social and economic criteria and can be spatially mapped. This other group of Catalans tried to mobilize to publicly show their disagreement over the secessionist project. Yet their arguments appear as reactive rather than based on any alternative evidence. Hence, they are co-opted by the central Spanish various governments' juridical positions, which supports a unified Spanish national identity, couched in the Constitution of 1978.

This article argues that an important aspect of the political confrontation is being played as an evidence struggle, where the various social actors produce different kinds of evidence to justify their actions in the political arena and mobilize support. Evidence is used to make a legal case and includes direct and circumstantial forms. Evidence is

expedite reform of the 1978 Constitution in order to include the public deficit ceiling in the Constitution, on the request of the European Commission, and the European Central Bank. See B.O.E. 2011, 233. Rodríguez Zapatero's government also passed a Labor Law deregulating the labor market. See B.O.E. 2010, 227. A second Labor Law was passed by the conservative PP government extending deregulation. See B.O.E. 2012, 36.

4. See B.O.E. 2013, 295, at 97912-13 ("Disposición adicional trigésima octava. Lengua castellana, lenguas cooficiales y lenguas que gocen de protección legal.”). 
used to make a moral case beyond legality and it includes mostly circumstantial evidence, especially historical forms of it. Finally, symbolic evidence is produced so as to incite emotional support. In this struggle for power and resources tied to territorial and cultural justification, these evidence struggles have saturated the political arena in such a way that other struggles are now invisible.

\section{AN OLD STORY}

The region of Catalonia has a long history of confrontation with Castilian power. This can be credited to the historical process of consolidation of the Spanish state, where different reigns preserving their statutes and privileges came to be dynastically united under the same Crown through the marriage of Isabel of Castile and Fernando of Aragon in the fifteenth century. During the sixteenth century, the power of Castile grew through colonization of the Americas and flourishing wool exports, while the commercial power of Catalonia (part of the Crown of Aragon) decreased as a result of the plague and of civil strife between the merchant and aristocratic elites and the peasant and artisan commoners. The Spanish Crown's involvement in European wars during that period, however, increased conflicts around fiscal pressure and military levies that directly impacted Catalan rural and urban populations and curtailed the powers of local institutions. As a response, a popular revolt ensued in 1640, and Catalan institutions joined the French dominion for a short time, before falling back under Spanish rule. ${ }^{5}$

As part of its statutes and privileges, the Principality of Catalonia had fiscal exemptions and a different jurisdiction. During the seventeenth century, Castile's power was challenged by foreign powers and internal revolts while simultaneously the institutional structure of the nation was being transformed into a centralized Monarchy-a modern state structure that the Catalan elite understood as a process of Castilianization that marginalized the role of regional institutions and challenged their power. The Catalan Constitutions and institutions, however, with their body of laws and their autonomous relation to the Crown, lasted-albeit with temporary interruptions-until the outcome of the War of Spanish Succession (a confrontation between the Hapsburg claimant to the throne and the Bourbon claimant, Philip V) in 1714. On September 11, 1714, the Bourbon troops entered Barcelona,

5. See generally John H. Elliott, The Revolt of the Catalans: A Study in the DECLINE OF SPAIN (1598-1640) (1963) (studying the decline of Spanish rule in the 17th century and the Catalan revolt against military exactions that expressed the distancing of this region from Castilian monarchy). 
and the Catalan region lost its Charters falling under the Decreto de Nueva Planta in 2016, basically being assimilated to the Castilian administrative realm albeit preserving its special civil law. This date was instituted as the Catalan national day in 1886.

\section{A Nineteeth Century Story}

The recent history of nation building in Catalonia is a nineteenth century story. ${ }^{6}$ It relates to European nation-state building and in particular to liberal (Enlightened period) models of the state which sought an end of ascribed privileges, a defense of private property, citizenship rule, equality before the law, and elected governing bodies. These enlightened models of the state were in confrontation with the privileges and structures of the Ancien Regime and with anti-liberal conservatism more generally. This history of nation building is also a struggle between class-based understandings of social conflict in the industrial centers and corporatist attempts to supersede them.

A central aspect of this is the breakdown of paternalistic moral economies in agriculture and industry alike that were being replaced by class confrontations in the urban industrial areas. In Catalonia, the confrontation with the liberal central state is a strong factor leading to conflict in the rural hinterland. One example of these conflicts is the series of civil wars (Guerras Carlistas) in Catalonia and in other regions of Spain that sought a return of traditional governmental structures. Although these traditionalist conflicts are extremely complex and underwent many transformations, by the end of the century they were often presented as defending historical identity, regional rights (fueros or Charters), and "freedoms" against the centralizing and homogeneizing liberal state of Spain. The Catalonian traditionalist movement was conservative and corporatist with strongholds in Berga, Solsona, Vic, and Manresa and was strongly influenced by the Church. ${ }^{7}$ For these traditional monarchists, the liberal centralizing state, with its uniformist trend, was seen as the first step toward egalitarianism and socialism. The first institution of the events of September 11, 1714, as the national Catalan celebration in 1886, for example, took the form of a Catholic holy mass organized by the conservative and traditionalist elites. Even so, the symbolic aspect of the event would explain that it

6. See Angel Smith, The ORIgins of CATAlan NATIONALiSM, 1770-1898 (2014); Josep Termes, De la Revolució de SeTembre a la Fi DE LA GuerRa Civil (1868-1939) (1999).

7. See El Carlisme. Sis Estudis Fonamentals (Jordi Canal et al. ed., 1993); Jesús Millán, Contrarevolució i mobilització a l'Espanya contemporània, 154 L'AVENC REVISTA D’HISTRÒRIA 16-23 (1991) (Spain). 
was attended by Valentí Almirall, the radical liberal, laic, federalist republican leader of the Centre Català (Catalan Center), a civil society association that was socially transversal and ideologically plural whose aim was to fight the homogenization of the liberal Spanish state and attain Catalan autonomy. ${ }^{8}$ Ideological tensions would split the Centre Català, however, and the conservative Lliga (League) would emerge as the leading force of Catalanism after 1888. Under its leadership it would soon promote another unitary platform (initially in defense of Catalan Civil Law), the Unió Catalanista (Catalanist Union) in 1891, ${ }^{9}$ that would draft the first independent Catalan constitution-like document, the Bases de Manresa (Manresa Foundations), in $1892 .{ }^{10}$ In the Catalan urban industrial areas, these were times of violent confrontation between workers and bourgeois industrialists mostly expressed in terms of tensions around ownership, labor rights, and redistribution. Here, industrial workers, increasingly drawn to internationalist movements and unionization, were suspicious of bourgeois appeals to their integration in a corporatist Catalan nation. ${ }^{11}$

Culturally, the Renaixensa (Renaissance) sponsored language and folklore recuperation following German romantic volksgeist (spirit of the people) movements of nation building. History, especially Medieval times, was underscored and instituted as the origin of the Catalan nation. This was narrated as a time of national expansion when Catalans controlled trade in the Mediterranean, when institutions such as the proto-parliament Consell de Cent (Council of One Hundred) were constituted, and when Catalan customary law-the Usatges (Customs) emerged. The Renaixensa was a strong moment of "invention of tradition" that served to strengthen the use of the Catalan language and highlight cultural difference. ${ }^{12}$

8. See generally Josep M. Figueres, FORJADOR DEL CATALANISME POLÍTIC (1990) (on Valentí Almirall, a major figure of nineteen century Catalan Republican nationalism).

9. See Josep Pich i Mitjana, La Génesis del catalanismo político. De los inicios de la restauración a la crisis del Centre Català, 68 HISPANIA 437 (2008) (SPAIN).

10. See JoAn Lluís PÉREz Francesch, Les Bases de MANREsa i El PROGRAMA POLÍtiC DE LA UNió CATALANisTa (1891-1899) (1992), at 93-126; Jordi Pujols et al., BASES PER A LA Constitució Regional CATAlana. MANRESA, MARÇ DE 1892 (1991) (facsimil editition of the document setting the guidelines for a constitution).

11. See generally MiQUEL IZARD, MANUFACTUREROS, INDUSTRIALES Y REVOLUCIONARIOS (1979).

12. See generally Joan Prat, El pairalisme com a model ideològic, 132 L'AVENÇ 34 (1989) (Spain), LLORENÇ PRATS, El MITE DE LA TRADICIÓ POPULAR (1988); SMITH, supra note 7, at 70-97 (on the emergence of traditions that become central to Catalan identity). 


\section{States of Exception}

The short-lived First Spanish Republic, founded in February 1873, was a federalist project that saw the first proclamation of the Catalan State in March 1873, a federalist declaration within a new institutional framework for Spain as a whole. In parallel, radical federalists activated an insurgent communal power movement, Cantonalismo, in Valencia, Castile, and Andalusia. After the Bourbon restoration of 1874, an important strand of federalist republicans in Catalonia would become the core of one of the various Catalan nationalist groups (under Valentí Almirall), and would vindicate a decentralized structure for Spain. Their program was republican, progressive, and liberal and believed Catalonia should become the economic and political engine of the rest of Spain. ${ }^{13}$

The turn of the century saw right-and left-leaning strands of Catalan nationalism converge and diverge at various moments. The dominant party during much of this period was the conservative Lliga Regionalista (Regionalist League), which also favored a decentralized administrative structure. In 1913, the central government published an executive order that enabled the consolidation of Diputaciones (regional administrative units) into larger units, an idea that had been put forward by Enric Prat de la Riba, the head of the Diputació de Barcelona and a member of the Lliga Regionalista. ${ }^{14}$ As a result the Mancomunitat de Catalunya (Commonwealth of Catalonia) was formed in 1914 and would last formally until 1925 and effectively until the Dictatorship of General Primo de Rivera in 1923.15 During ten years, this commonwealth would develop, among others, infrastructures, such as roads and telephone networks; educational programs geared to engineering and agriculture; agricultural cooperatives to promote commercialization; pedagogical innovation with the introduction of the Montessori system; and cultural programs that strengthened the Catalan language and identity. While this bourgeois project of economic and cultural development took place, Barcelona was prey to incredibly violent confrontations between labor-increasingly organized in unions - and the industrial bourgeoisie with its army of gunmen. ${ }^{16}$

The advent of the Second Republic in Spain (April 14, 1931) following municipal elections created another opportunity for

13. See generally VALENTí AlMiRAll, ANTOLOGIA DE TEXTOs (2011) (edited collection of the works of a major figure of nineteen century Catalan Republican nationalism).

14. See EnRICh Prat DE LA Riba, LA Nacionalitat Catalana (1910), at 101-115; TERMES, supra note 7, at 157-266.

15. TERMES, supra note 7 , at 251 .

16. Id. at 227-32, 293-308. 
institutional change. In Catalonia, Francesc Macià, leader of Esquerra Republicana de Catalunya (Catalan Republican Left, ERC), proclaimed the "Republica Catalana com Estat integrant de la Federació Ibérica" (the Catalan Republic a state integrating the Iberian Federation). In so doing, he made an appeal to recent history (the First Republic) and to its promise of a federal political framework, but this was now a unilateral declaration, one that proclaimed the Catalan State and the Catalan Republic before affirming the will to confederate with the other Spanish Republics. ${ }^{17}$ In 1932, the first Catalan Estatut d'Autonomia (Charter of Autonomy) was instituted and lasted until the invasion of Catalonia by the Francoist army in 1939.

In October 1934, another declaration of a Catalan State (again within the Spanish Republic) took place. This move was allegedly aimed at preserving the Republic against the assault of the anti-liberal right after the entry of the Confederación Española de Derechas Autónomas (Spanish Confederation of the Autonomous Right, CEDA)-an extreme right party-in the populist government headed by Alejandro Lerroux; but it was also an attempt to preserve liberal democracy against the tides of the revolutionary left. The event was part of the Revolution of October 1934, a working class uprising against the extreme right led by the socialist union (especially in Asturias and Catalonia). The thenpresident of the Catalan autonomous government, Lluís Companys (ERC), announced the Catalan State as a safe harbor for a Spanish federal republic in its protest against fascism. ${ }^{18}$ In so doing, he both safeguarded the articulation of Catalonia to a wider political entity-the Spanish federal republic - and went beyond the Charter of Autonomy by instituting a sovereign state. The three proclamations of the Catalan State referred to above, all occur in "states of exception" where a republican moment emerges both in its revolutionary and vulnerable aspects.

17. Macià did several proclamations of the Catalan Republic on April 14th, and they are slightly different in how they present the relationship of the new political entity with the rest of Spain. Some proclomations present the integration into a confederation as a process and desire, others as an established fact. J.Cebrián, A. Rodríguez, J. Bassas, El dia que Barcelona va proclamar la República, Barcelona.cat (Apr. 11, 2013) available at https://www.youtube.com/watch?v=J064hFCfFG4; Proclamación de la República en Barcelona, LA VANGUARDIA, miércoles 15 de abril 1931, at 6-7, available at http://hemeroteca.lavanguardia.com/edition.html?bd=15\&bm=04\&by=1931\&x=21\&y=14.

18. “. . . [P]roclama el Estado Catalán de la República Federal Española, y al establecer y fortificar la relación con los dirigentes de la protesta general contra el fascismo, les invita a establecer en Cataluña el gobierno provisional de la República, que hallará en nuestro pueblo catalán el más generoso impulso de fraternidad en el común anhelo de edificar una República Federal libre y magnífica.”Jornadas Trágicas: Alzamiento del Gobierno de la Generalidad, LA VANGUARDIA, Oct. 9, 1934, at 6 (Spain). 
Franco's dictatorial regime (1939-1975) eliminated the Estatut of the second Republic, recentralized institutions, and imposed Castilian as the only language of the Spanish state. This does not mean, however, that Catalans were homogeneously repressed or that they suffered equally under the new regime. Indeed, a sizable part of the Catalan elite supported a regime they saw as a bulwark against communism, and many benefitted from new patron-client networks and privileges. 19 Repression hit mostly those that had been affiliated with the left, including anarchists, trade unionists, socialists, communists, and the Catalan national left-especially those that had held office. Symbolically, the compulsory use of Castilian in all administrative communications and the interdiction to speak Catalan in public (which could be discretionally enforced) was felt as an intimate humiliation by Catalan speakers, which made language an extremely sensitive foundation of Catalan political identity. ${ }^{20}$

Starting in the mid-1960s, some twenty years after the end of the Spanish Civil War (SCW), the opposition to the Francoist regime was getting organized. First and foremost, a strong trade union movement emerged that challenged work conditions and agitated for democracy and political freedoms. ${ }^{21}$ At the same time, various nationalist movements were re-organizing in the country; some like the Basque ETA were using violent means while others were reviving clandestine parties from before the SCW such as the Partido Nacionalista Vasco (Basque Nationalist Party, PNV) or the Esquerra Republicana de Catalunya (Catalan Republican Left, ERC) who maintained governments in exile in Paris. In Catalonia, the strongest party at the time was the Partit Socialist Unificat de Catalunya (Catalan Unified Socialist Party, PSUC), a communist party that had dominated the last

19. See generally IGNASI RIERA, Els CATALANES DE FRANCO (1998) (presents the collaboration of the Catalan bourgeoisie and aristocracy with the dictatorship).

20. The official enforcement of Castilian as the language of administration and culture had precedents in various moments of centralization during the eighteenth and nineteenth centuries. The Catalan elites, however, generally embraced Castilian as the language of power; they went to religious schools where the teaching language was Castilian and they interacted mostly in this language for official and public matters, with the relative exception of those that supported the cultural movement of the Reneixensa and were part of political catalanism. This had created a situation of diglossia related to class, where elites used both Castilian and Catalan according to the situation, and laboring classes only Castilian (when immigrant) or Catalan (when local). See Joan-Lluís Marfany Per a la història de la introducció del castellà a Catalunya. Alguns problemes $i$ qüestions de mètode, ESTUDI GENERAL 22 (2002) 65-87, at 86-87. Hence, language repression hit mostly the urban middle class (petty commerce, civil servants, liberal professions), cultural revivalist, and the rural peasantry.

21. See Pere Ysàs, El movimiento obrero durante el franquismo. De la resistencia a la movilización (1940-1975), CUADERNOs DE HisTORIA CONTEMPORÁNEA 30 (2008), 165-184. 
period of the war in Barcelona and had strong ties with the emerging labor movement. Simultaneously, cultural, educational, and religious associations (Òmnium, Virtelia) became key spaces for recuperating language, folklore, and identity. The latter were tolerated by the regime that confined identity aspirations to regionalist cultural associations and trusted the Catholic Church as an ally against "extremism." These associations would become central to the development of a conservative strand of Catalan nationalism that connected with nineteenth-century Catholic regionalism.

In 1971, the Assamblea de Catalunya (Catalan Assembly), a unitary opposition to the Francoist regime by all democratic parties and civil society associations (including the Communist PSUC), was formed. The program was to fight for democracy, for amnesty of political crimes, and for the recuperation of a Charter of Autonomy as before the SCW. This movement was dissolved after the first democratic elections in 1977, but its name was recuperated in 2012 by the Assamblea Nacional de Catalunya (Catalan National Assembly, ANC) in a symbolic attempt to link its program to its predecessor's fight against the dictatorship.

The Spanish Transition (1975-1978) was internationally hailed as a model one. It was based on political agreements and compromises between different parties and on an amnesty law that superseded all political crimes, such as the alleged ones of those that had opposed the dictatorship and suffered Francoist repression and the ones of those that had supported the regime and would therefore never be taken to court for their crimes. While the "fathers of the constitution" 22 were debating the new institutional framework, violently repressed demonstrations claiming for "Llibertat, Amnistia i Estatut d'Autonomia" (Freedom, Amnesty, and Charter of Autonomy) took place in Barcelona in the winter of $1976 .{ }^{23}$ The first massive demonstration of the postFrancoist era took place in Barcelona on September 11, 1977, under the slogan "Llibertat, amnistia $i$ estatut d'autonomia." Participation was described as featuring one million demonstrators. ${ }^{24}$ In 1978, the Constitución Española (Spanish Constitution, CE) was ratified in referendum on December 6, 1978, and in 1979, the Second Catalan Estatut d'Autonomia was instituted within the framework of the CE.

22. The Fathers of the Constitution in charge of elaborating the proposal were seven jurists and politicians, including a representative of the communist party PSUC and a representative of the "Catalan minority" but no representative of the Basque Nationalist party who had refused to participate.

23. See generally DAVID BALlester \& MANEL Risques, TEMPs D’AMnistia. Les MANIFESTACIONS DE L'1 I EL 8 DE FEBRER A BARCELONA (2001).

24. See Onze setembre 1977: Manifestación decisiva en la historia de Cataluña, LA VANGUARDIA ESPAÑOLA, Sept. 3, 1977, at 3 (Spain). 


\section{NATIONALISM AND AUSTERITY: PARALLEL CHRONOLOGIES}

After a brief, symbolic return from exile of the last president of the Catalan Generalitat (Catalan autonomous government), Josep Tarradellas, from the ERC Catalan Republican Left, Catalonia had a nationalist conservative president for twenty-three years (Jordi Pujol). ${ }^{25}$ A reason given for this is that the electoral system favors the rural under-populated regions as opposed to the urban industrial areas. In 2003, a coalition of left parties (including socialists, republican left, and socialist \& ecologist union) came into power in the Generalitat. One of their main projects was to propose a new Estatut that would enlarge the devolution of power to Catalan institutions (especially in juridical and fiscal domains). From 2004 to 2005, the Catalan Parliament debated the new Estatut d'Autonomia, and in 2006, a third Estatut was voted in by the Catalan Parliament. It was then amended by the Spanish Parliament, and the national conservative party, Partido Popular (PP), took it to the Constitutional Court (in 2006) where the Estatut was truncated in a ruling that deleted various articles and restrictively interpreted others (the ruling was pronounced on June 28, 2010). ${ }^{26}$ The main changes opposed the status of Catalonia as a "nation", limited the creation of a separate judicial system, restricted fiscal decisions, and insisted on the co-official status of the Spanish language. This is the Estatut currently in place, which nevertheless allows for ample autonomy. Although the actual Charter enables the Catalan government to manage important resources, some directly levied and others directly transferred by the state, the fiscal deficit remains one of the central grievances against the state.

As a result of the Constitutional Court's decision, on July 10, 2010, a second massive demonstration under the slogan "Som una nació $i$ nosaltres decidim" (We are a nation and we decide) took place in Barcelona. ${ }^{27}$ The term nació (nation) had been interpreted by the

25. Jordi Pujol, his wife, and several of his children have since been indicted in cases of corruption and tax evasion. Europa Press La Audiencia Nacional pide a Andorra todos los datos sobre las fundaciones panameñas utilizadas por el clan Pujol, PúBLICO (Aug. 21, 2017 7:07 PM).

https://www.publico.es/politica/corrupcion-familia-pujol-audiencia-nacional-pide-andorradatos-fundaciones-panamenas-utilizadas-clan-pujol.html.

Oriol Solé Altamira Los Pujol Ferrusola, una familia imputada con frentes judiciales en Madrid y Barcelona, EL DIARIO.ES (Apr. 26, 2017 7:36 PM)

https://www.eldiario.es/catalunya/politica/judiciales-Pujol-reparten-Madrid-

Barcelona_0_637286681.html.

26. See TRIBunal Constitucional, B.O.E. n. 172, Jul. 16, 2010 (Spain).

27. The major newspapers inform of over one million participants. See Catalunya sentencia, LA VANGUARDIA, July 11, 2010, at 1 (Spain). 
Constitutional Court as excluding sovereignty with the argument that the only sovereignty resides in the Spanish people. The use of nacio in the original Estatut, however, was clearly aimed at establishing the substance of a right to a state, a sovereignty. It sought to supersede the term nacionalidad (nationality) that had been negotiated and accepted in the Spanish Constitution of 1978 to refer to the "historical" autonomous communities - those that had earned the status of autonomous communities before the dictatorship, thus differentiating between "regions" and "nationalities." 28 Shortly after, in December 2011, the Association of Municipalities pro-Independence (AMI) was created and has grown to include 83 percent of municipalities representing 43 percent of Catalan population, the major exceptions located in the urban areas of Barcelona and Tarragona. ${ }^{29}$ The first president of the AMI was the Mayor of Vic from the conservative party Convergència $i$ Unió (Convergence and Union, CiU), and he was replaced in 2015 by Carles Puigdemont, Mayor of Girona. He would very soon be selected by his party, CiU, as a replacement candidate for the position of president of the Generalitat after the elections of September 2015. The AMI has had an important role in shifting people's focus toward the sovereignty issue and away from austerity problems.

At the same time, in 2010, the financial crisis, the bursting of the housing bubble and subprime mortgage defaults, struck the country. In Spain, the bailing out of banks, the conditionalities attached to EU support, and the austerity cuts mobilized large protest movements. The new conservative government of Catalonia, voted in November 2010, was at the forefront of these structural adjustment measures as Artur Mas (CiU), conservative neoliberal, became president and immediately implemented important austerity cuts in health, education, and social services.

Protests against austerity throughout Spain culminated in the 15-M Indignados movement of 2011. Demonstrations in all Spanish Plazas spread from the initial occupation of Puerta del Sol in Madrid and Plaça Catalunya in Barcelona. The latter was violently repressed by the Mossos de Esquadra (local police) on May 27, following orders from the Catalan government's interior Minister Felip Puig, of the conservative

28. The distinction between nationality and nation is often ambiguous: in the turn of the century, political writers where the former appears often as the substance of the latter. Both seem to refer to the "character" of the total social organism, "the spirit of the people", or "national conscience" following volkgeist ideas. See PRAT DE LA RIBA, supra note 15, at 77-100; ANTONI ROVIRA I. VIRGILI, El NACIONALISME at 37, 81-84 (1916).

29. See Associació de Municipis per la Independència, WIKIPEDIA, https://ca.wikipedia.org/wiki/Associaci\%C3\%B3_de_Municipis_per_la_Independ\%C3\%A8n cia (last visited Sept. 3, 2018). 
party $\mathrm{CiU}$ and a vocal Catalan nationalist; it was the first violent eviction of the 15-M movement. ${ }^{30}$ During 2011 and 2012, many massive demonstrations (up to five hundred thousand) against austerity occurred all over Spain in support of public health and education. The phenomenon of mareas (tidal waves), in support of public health (White tide), education (Green tide), and the environment (Blue tide) became ubiquitous from 2012 to 2014. In Catalonia, the phenomenon of the tides was also present while the Plataforma de Afectados por la Hipoteca (platform of mortgage victims, $\mathrm{PAH}$ ), challenged the legitimacy of the mortgage defaulters' eviction law and eventually leveraged support from a European Court of Justice ruling that forced Spain to amend its law. ${ }^{31}$ This anti-eviction movement spread from Catalonia to the rest of the state and became the expression of the impact of the financial crisis on ordinary people and the development of collective resistance. At the end of 2013, workers from small leftist unions (SAT, CGT, CNT), together with civic associations (Frente Cívico, PAH) and the various tidal waves (White, Green), organized a "March of Dignity" to Madrid from all the regions in Spain. The first March of Dignity took place on March 22, 2014, in Madrid and gathered around one million people under the slogan Pan, trabajo y techo (Bread, Work and a Roof). ${ }^{32}$ Many participants in these mobilizations would become key to the development of the new party Podemos that supported a strong critique towards the Constitution of 1978 and the Transition agreements.

In this conjuncture of popular mobilizations against austerity and in support of constitutionally protected welfare rights, the conservative Catalan government increased its support to an independent option and the national issue became hegemonic in the attention of the media. Although many demonstrations referring to austerity and health and education cuts have continued filling the streets, they are minimized by the press. Austerity cuts kept being implemented aggressively in Catalonia by the Catalan Minister (conseller) of economy who justified

30. See Enrique Figueredo, Puig actúa y el 15-M rebrota, LA VANGUARDIA, May 28, 2011, at 36 (Spain).

31. See Juan Carlos Benito Sánchez, The CJEU and Spanish mortgage law: consumer protection, floor clauses and accelerated repayment, EU LAW ANALYSIS (Feb. 20, 2017), http://eulawanalysis.blogspot.com/2017/02/the-cjeu-and-spanish-mortgage-law.html.

32. All of these claims refer to rights included in the Spanish Constitution: "Art. 27. Todos tienen el derecho a la educación"; "Art. 35. Todos los españoles tienen el deber de trabajar y el derecho al trabajo, a la libre elección de profesión u oficio, a la promoción a través del trabajo y a una remuneración suficiente para satisfacer sus necesidades y las de su familia"; "Art. 43. 1. Se reconoce el derecho a la protección de la salud. 2. Compete a los poderes públicos organizar y tutelar la salud pública a través de medidas preventivas y de las prestaciones y servicios necesarios"; "Art.47. Todos los españoles tienen derecho a disfrutar de una vivienda digna y adecuada.” C.E., B.O.E. n. 311, Dec. 29, 1978 (Spain). 
the need to carry on structural adjustment because of the Catalan fiscal deficit with the state: Madrid ens roba (Madrid steals from us) has been the slogan.

Institutional declarations defending the right to self-determination became frequent: on January 23, 2013, the Catalan Parliament approved a "Declaration of sovereignty and of the Catalan people's 'Right to decide." On March 2014, the Constitutional Court declared the Catalan aspiration to sovereignty unconstitutional because "only the Spanish people is sovereign," 33 but on June 26, 2013, a commission under the name of Pacte Nacional pel Dret a Decidir (National Agreement for the Right to Decide) that includes public institutions, parties, and civil society entities was created. ${ }^{34}$ Of the civil society entities, two became central to the organization of a popular, emotionally charged movement: Òmnium (founded in 1961 as a cultural association), and the Assamblea Nacional Catalana (Catalan National Assembly, ANC, founded in March 2012). The name of the latter is a direct reference to the anti-Francoist Assamblea de Catalunya, but the ANC is different. Its only project is to create a grassroots movement towards independence without any further explicit political-economic content. The ANC, with the support of Òmnium, will be in charge of organizing all the September 11 demonstrations from 2012 on, ${ }^{35}$ in an

33. Suplemento del Tribunal Constitucional, "BOE" 87, de 10 de abril de 2014, Sec.TC. 77, at 85 https://www.boe.es/diario_boe/txt.php?id=BOE-A-2014-3885.

34. The entities participating are: Parlament de Catalunya, l'Institut d'Estudis Catalans, les Diputacions de Catalunya, l'Ajuntament de Barcelona, l'Assemblea Nacional Catalana, Òmnium Cultural, Convergència i Unió, Esquerra Republicana de Catalunya, Iniciativa per Catalunya Verds - Esquerra Unida i Alternativa, Candidatura d'Unitat Popular, la Unió General de Treballadors, la Comissió Obrera Nacional de Catalunya, la Unió Sindical Obrera de Catalunya i la Intersindical-CSC. See Pacte Nacional pel Dret a Decidir, WIKIPEDIA, https://ca.wikipedia.org/wiki/Pacte_Nacional_pel_Dret_a_Decidir, (last visited Sept. 3 2018); El Pacte Nacional pel Dret a Decidir fa una crida a la societat civil a implicar-se en la consulta "des del civisme" $i$ amb una actitud "constructiva", Generalitat DE CATalunya: SAla DE Premsa, (Feb. 19, 2014, 6:25 PM), http://premsa.gencat.cat/pres_fsvp/AppJava/notapremsavw/249732/ca/pacte-nacional-peldret-decidir-fa-crida-societat-civil-implicar-consulta-des-civisme-i-amb-actitud-

constructiva.do.

35. The slogans and performances of these multitudinous events are: 11 September 2012, massive demonstration "Catalunya, nou Estat a Europa" (Catalonia, a new state in Europe); 11 September 2013, 400km human chain (from north to south of the Catalan territory); 11 September 2014, massive demonstration, a human giant "V" is formed in the streets of Barcelona; 11 September 2015, massive demonstration under the slogan "Via Lliure a la Republica Catalana" (free way to the Catalan republic); 11 September 2016, massive mobilization under the slogan "A punt" (Ready); 11 September 2017, participants gathered in a giant cross meaning "adding more" and wore a yellow t-shirt with the sentence "referendum is democracy." See JORDI CANAL, CON PERMISO DE KAFKA. EL PROCESO INDEPENDENTISTA EN CATALUÑA (2018), at 359-375. 
annual performance of massive support for independence. Organizers are extremely careful to target the international audience to visually express the totalizing unity of the Catalan people's identity and desire to be a sovereign nation. The media are essential elements in these demonstrations. ${ }^{36}$

In 2014, the Catalan government commissioned a Llibre Blanc sobre la Transicio Nacional de Catalunya (White Book on the National Transition of Catalonia) ${ }^{37}$ from the Consell Assessor per a la Transició Nacional (Advisory Committee for the National Transition), headed by a prestigious Catalan jurist who had been vice president of the Constitutional Court. It was presented in September 2014 coinciding with the official announcement of the November 9 Referendum on Catalan independence, the first referendum that was ruled illegal by the Constitutional Court (CC) and was re-named a "participation process."38 On September 27, 2015, elections to the Autonomous Parliament took place. The two parties supporting Catalan national sovereignty, CiU and ERC, joined together in a coalition named Junts pel Sí (Together in Support of Yes) and agreed to make these elections a plebiscite for independence, disregarding any other issue or program. They got a majority of seats with less than 50 percent of the vote ${ }^{39}$ but

36. The links between the ANC and the Catalan institutions are very strong: Carme Forcadell, ANC president, became the President of the Catalan Parliament in 2015. Jordi Sanchez, the ANC president until March 24, 2018, was candidate for the Presidency of the Generalitat after the December 21, 2017 elections. Both are presently imprisoned awaiting trial. CANAL supra at 169-171, 201-204; JORDI AMAT, LA CONFABULACIÓ DELS IRRESPONSABLES (2017) at 70-78; Perfil - Quim Torra, exlíder d'Òmnium proper a Puigdemont per presidir el Govern, DIARI DE GIRONA (May 10, 2018 8:34 PM) https://www.diaridegirona.cat/catalunya/2018/05/10/perfil-quim-torra/912795.html.

37. See generally Generalitat De CATAlunya, Llibre BlanC sobre la Transició NACIONAL DE CATALUNYA: SÍNTESI (2014) http://www.govern.cat/pres_gov/ AppJava/govern/gransreptes/transicionacional/275999/llibre-blanc-transicio-nacionalcatalunya.html (arguing the need for an independent state and defining its basic structure).

38. The questions of the participatory process were: a) Do you want Catalonia to become a State? (Yes/No); If the answer is in the affirmative: b) Do you want this State to be independent? (Yes/No). Turnout estimates published by media outlets range between $37.0 \%$ and $41.6 \%$ with $80.8 \%$ of the cast votes supporting the Yes-Yes option, $10.1 \%$ the Yes-No, 4.5\% the No option. See Fernando J. Pérez \& Pere Ríos, 1,8 millones de personas votan por la independencia catalana en el 9-N, EL PAís (Nov. 10, 2014, 4:16 PM), https://elpais.com/politica/2014/11/09/actualidad/1415542400_466311.html; João França, Mapa. La participación y los resultados del 9- $N$ comarca a comarca, EL DIARIO.ES (Nov. 9, 2015, 5:37 PM), https://www.eldiario.es/catalunya/MAPA-participacioncomarca_0_322668045.html.

39. Junts pel Sí got $39.54 \%$ of the vote and 62 seats, CUP (anti-capitalist independentist party) got $8.2 \%$ of votes and 10 seats, hence the partisans of national sovereignty added $47.74 \%$ of the votes but together had a majority of seats (72 seats out of 135). Eleccions al Parlament de Catalunya 2015, Generalitat De Catalunya, 
they considered they had a mandate to pursue the Full de ruta del process sobiranista català (Pathway of the Catalan sovereign process) signed in March 2015 by these parties. Honoring this mandate resulted in a cascade of events which I will briefly enumerate:

In January 2016 the Comisió d'Estudi del Procés Cosntituent (Committee for the Study of the Constituent Process) was formed and headed by the president of Òmium.

On October 6, 2016, the Parliament resolved to carry on a referendum based on the "imprescriptible and inalienable right of Catalonia to self-determination." It would either be agreed by the state or carried out unilaterally (Referendum Unilateral d'Independència, $R U I)$. The Spanish government refused to agree to the referendum.

The RUI was announced in June 2017 to be carried out on October 1, 2017. The referendum question asked: "Do you want Catalonia to be an independent state in the form of a Republic?" Neither the Spanish Parliament majority nor the minority in the Catalan Parliament (although representing a majority of votes) supported the RUI. Many believed the referendum did not have procedural guarantees. To many, it was an expression of the will to act beyond the rule of law.

On September 6 and 7, 2017, two unconstitutional laws (the referendum law and the transition law) were approved by the majority in the Catalan Parliament against the advice of the jurists in the Parliament and the rulings of the Committee of Statutory Guarantees. ${ }^{40}$

The CC declared the October 1 referendum illegal, ${ }^{41}$ and the Mossos d'Esquadra (Catalan police, MdE) was ordered to prevent the voting by requisitioning ballot boxes, preventing printing and distribution of ballots, and blocking the opening of polling stations. But the MdE were put under the command of the National Police who were sent to Catalonia together with the Civil Guard allegedly to support the MdE. In reality, the central government did not trust the MdE because their director had been replaced in July with a Catalan independence

\footnotetext{
http://www.gencat.cat/governacio/resultatsparlament2015/resu/09AU/DAU09999CM_L2.h tm (last visited Sept. 3, 2018).

40. See Proposició de llei del referèndum d'autodeterminació, PARLAMENT DE CATALUNYA, https://www.parlament.cat/web/activitat-parlamentaria/siap/index.html? STRUTSANCHOR1=detallExpedient.do\&criteri=202-00065/11\&ad=1 (last visited Sept. 3, 2018); Proposició de llei de transitorietat jurídica $i$ fundacional de la república, PARLAMENT DE CATALUNYA, https://www.parlament.cat/web/activitatparlamentaria/siap/index.html?STRUTSANCHOR1=detallExpedient.do\&criteri=20200066/11\&ad=1 (last visited Sept. 3, 2018); Arturo Puente, El Parlament aprueba la ley para declarar la independencia tras el 1-O, EL DiARIO.ES (Sept. 8, 2017, 12:47 AM), https://www.eldiario.es/catalunya/politica/Parlament-Catalunya-aprueba-declararindependencia_0_684182584.html.

41. See Tribunal Constitucional, B.O.E. n. 256, Oct. 24, 2017 (Spain).
} 
supporter, Pere Soler. ${ }^{42}$

Committees for the Defense of the Referendum were formed that mobilized civil society to enable voting. For example, parents stayed with their children overnight in schools allegedly doing extra-curricular activities so that they could open them as polling stations in the morning. ${ }^{43}$ People went to vote and tried to prevent the police from closing the polling stations and taking the ballot boxes, defending their right to vote. Repression was violent and some images became viral.

The referendum results included a turnout of 43 percent: 90.2 percent of "Yes"; 7.8 percent of "No"; the rest white or null. ${ }^{44}$ The Catalan government considered this a resounding victory that ratified the mandate to pursue the path towards independence. On October 10, 2017, the president of the Generalitat, Carles Puigdemont, unilaterally declared independence (DUI) and immediately suspended it to enable dialogue with the state. The president of Spain, Mariano Rajoy from the conservative PP, asked for a clarification as to whether independence had been declared or not. Receiving no response, on October 21, 2017, he activated Article 155 of the Constitution that suspends the autonomy of a region after submitting the provision to the Senate and earning a majority vote. The Catalan government could have de-activated the application of Article 155 if it called for elections but finally decided against it. Instead, pro-independence parties registered two resolutions in the Catalan Parliament, one certifying Catalan independence, the other stating the beginning of the constituent process and the application of transition law. ${ }^{45}$

42. Europa Press, Portavoz del Govern sobre el nuevo director de Mossos: "No es momento de reproches, sino de confianza", EL DIARIO.ES (July 18, 2017, 02:43 PM), https://www.eldiario.es/politica/Portavoz-Govern-Mossos-reprochesconfianza_0_666333857.html.

43. Sergi Pitarch \& Pau Rodríguez, Vecinos y familias pasan la noche en decenas de colegios electorales para garantizar su apertura el 1-O, EL DIARIO.ES (Sept. 29, 2017, 05:31 PM), https://www.eldiario.es/catalunya/Vecinos-familias-empiezan-electorales-garantizar _0_691881409.html.

44. Resultados definitivos del referéndum del 1 de octubre, EL DiARIO.ES (Oct. 6, 2017, 5:05 PM), https://www.eldiario.es/catalunya/Resultados-definitivos-referendum-octubre _0_694331349.html.

45. See Arturo Puente, Puigdemont suspende la declaración de independencia para buscar el diálogo, EL DIARIO.ES (Oct. 10, 2017, 07:39 PM), https://www.eldiario.es/catalunya/politica/Puigdemont-independencia-Catalunyamediacion-internacional_0_695730833.html; Este es el texto firmado por los diputados independentistas en el Parlament, EL DIARIO.ES (Oct. 10, 2017, 10:20 PM), https://www.eldiario.es/catalunya/texto-firmado-diputados-independentistas-

Parlament_0_695731629.html; Iñaki Pardo Torregrosa, El Gobierno cree que el requerimiento queda sin respuesta y anuncia que activará el artículo 155, LA VANGUARDIA (Oct. 19, 2017, 10:25 AM), https://www.lavanguardia.com/politica /20171019/432178812964/gobierno-articulo-155-requerimiento-puigdemont-no-respuesta- 
On October 27, 2017, the president of the Spanish government dissolved the Catalan Parliament and called for elections on December 21,2017 . The results of the elections, again presented as a plebiscite for independence, gave a majority of 70 seats to the pro-independence parties (ERC, JxCat, and CUP) with a total of 47.5 percent of votes. ${ }^{46}$

In the meantime, the juridical process against those responsible for the RUI and the DUI started. Some were committed to preventive detention, some flew into "exile," and some were released with bail pending trial. The judge charged them with the crimes of "rebellion," "sedition," "disobedience," and "misappropriation of public funds."

\section{The Judicialization of Politics: Making a Legal Case}

In the open conflict that confronts citizens and institutions around the right of secession of Catalonia, the legal question is paramount. For some, the repeated anti-constitutional actions of Catalan institutions are a dangerous attack to the rule of law that require a juridical response. For others, these actions are only an expression of a political problem that can only be resolved through negotiation and agreements. Those that support the latter interpretation point to the negative aspects of a "judicialization of politics" where political actors are charged and taken to court or, worse, imprisoned for their politically legitimate deeds. They claim that a political conflict between the Catalan nation and the Spanish state is being shifted to the juridical arena through the constant appeal to the $\mathrm{CE}$ and the CC. Those supporting this position (mostly pro-independence but not exclusively) underscore grievances and present factual evidence of a political character - although often tied to past juridical rulings-such as the censoring by the CC of the 2006 Estatut d'Autonomia passed in the Catalan Parliament and validated in a referendum by the Catalan people; the fiscal deficit of Catalonia in relation to the state; the lack of investment in infrastructures by the state (especially the blockage of the "Mediterranean corridor," a crucial logistic element for the development of the region); and the interference with the education system in detriment of Catalan language immersion.

The political grievances also include the vindication of a different institutional articulation with the state that would take into account the

\footnotetext{
rajoy.html; Constitución Española: Sinopsis Artículo 155, ConGRESO, http://www.congreso.es/consti/constitucion/indice/sinopsis/sinopsis.jsp?art=155\&tipo=2 (last visited Sept. 3, 2018).

46. See Eleccions al Parlament de Catalunya 2017, Generalitat de Catalunya, http://gencat.cat/economia/resultats-parlament2017/09AU/DAU09999CM.htm?lang=es (last visited Sept. 3, 2018).
} 
historical particularity and ancient institutions of Catalonia, an aspect that is generally taken back to Medieval institutions and pacts and stresses the more recent republican periods of self-government. The date of 1714 (described above) that signals the loss of the Spanish War of Succession to the Bourbon monarch followed by the loss of the Charter of privileges of the Catalan Principality has become the symbol of the main political grievance: homogenization under an increasingly liberal centralized modern state.

Presently, however, the accusation of judicialization has become central to the development of the conflict between Catalan sovereignty parties and their supporters, and the state. The state has repeatedly refused dialogue in terms of possible political agreements showcasing the evidence that a number of Catalan representatives (president, vicepresident, president of the Parliament, members of government, other representatives), Catalan police commanders (MdE), and civil society leaders (the presidents of the ANC and Òmnium) have committed illegal acts. The charges of "rebellion," "sedition," "disobedience," and "misappropriation of public funds" depend on individual responsibility. In the case of the charge of rebellion, the main issue is to prove that there was "a violent rising" against the constitutional order, something that hinges on the definition and scope of the concept of "violence" and on the interpretation of certain popular tumults and collective aggressive actions. ${ }^{47}$

The juridical evidence is based on existing documents that prove the intention and organization of secession (White Book of 2014, "Enfocats" guidelines) ${ }^{48}$ on the actions that were taken knowingly against the law in the Parliamentary sessions of September 6 and 7 (the law of referendum and the law of transition), on the actions enabling the illegal referendum to take place, and on the actions and documents unilaterally declaring independence after the results of the illegal

47. Violence for certain crimes (e.g. gender violence) spans from speech acts and psychological harassment to actual physical violence. In the case of rebellion, the meaning of "violence" in the intent of the legislators seems to have been restricted to the use or threat of physical violence (e.g. like in an armed uprising). See José Precedo, ENTREVISTA: Javier Álvarez, catedrático de Derecho Penal, EL DiARIO.ES (Nov. 14, 2017, 09:35 PM), https://www.eldiario.es/politica/dirigentes-independentistas-barbaridadesconducta-rebelion_0_707980198.html; Javier Pérez Royo, La rebelión del Govern: un delito imaginario, ARA.CAT (Dec. 13, 2017, 08:52 PM), https://www.ara.cat/es/opinion/javierperez-royo-rebelion-govern-delito-imaginario_0_1923407880.html.

48. See The "Auto" referenced is Auto de 21 de marzo de 2018. It can be found here http://www.poderjudicial.es/cgpj/es/Poder-Judicial/Tribunal-Supremo/NoticiasJudiciales/El-juez-Pablo-Llarena-procesa-por-un-delito-de-rebelion-a-13-de-losinvestigados-en-la-causa-por-el-proceso-secesionista-de-Cataluna (last visited Dec.13, 2018) (Spain). 
referendum. The preventive imprisonment without bail of Oriol Junqueras (ERC) then vice president of the Catalan government, and of the presidents of the civil society associations (ANC and Òmnium, popularly known as "the Jordis") have been based on the evidence of "danger of flight" as president Carles Puigdemont (PdCAT) and several other members of the then Catalan government had escaped into "exile" in Brussels.

The use of juridical argumentation, however, is not limited to the state system, as the parties supporting a Catalan "right to decide" (not all of them secessionist, as some favor a federalist approach) appeal to the "fundamental rights of self-determination" of a "people" where the main difficulty hinges on the definition of "people." Although some use the historical account of the 1714 defeat as the evidence of territorial "occupation" by a centralizing state, the jurists and politicians writing the Llibre Blanc sobre la Transicio Nacional de Catalunya (White Book on the National Transition of Catalonia of 2014) appeal to the case of Kosovo's unilateral declaration of independence and an International Court of Justice advisory opinion (2010) that it was in accordance with international law. 49 They stress the right of a "permanent minority" that is being unjustly treated by the state to exercise the right of selfdetermination. The "national or territorial minority" of a democratic state can have their "reasonable aspirations to self-government and the agreements of territorial autonomy" systematically violated by the central state, and the only solution is full sovereignty. ${ }^{50}$

This is a juridical argument based on another kind of evidence: that of an existing "national or territorial minority" whose collective rights are systematically violated within a state. The coupling of a "national" and "territorial" argument produces ambiguity as to the actual constituents - the collective defined as "the people" - whose aspirations and rights are being violated. The juridical argument is that these are "fundamental" universal human rights regarding the freedom of the Catalan people and hence are of a higher (juridical and moral) order than the Spanish Constitution.

49. See Advisory Opinion of the International Court of Justice: Accordance with international law of the unilateral declaration of independence in respect of Kosovo, UNITED NATIONS AND THE RULE OF LAW, https://www.un.org/ruleoflaw/ files/ef_KOS_Advisory-opinion_bilingual.pdf (last visited Oct. 17, 2018).

50. Generalitat DE CATAlunYa, supra note 38, at 20 ("Aquestes violacions inclouen la impossibilitat de conciliar demandes (raonables) d'autonomia regional amb l'estructura de l'Estat i la intervenció i el qüestionament (sistemàtic) de l'autonomia territorial per part de l'Estat central malgrat els pactes formals existents . . . L L'únic remei possible a aquesta situació és la modificació de les relacions entre la majoria i la minoria territorials fins a posar-les en un pla d'estricta igualtat, concedint l'estatus de plena sobirania a la minoria nacional."). 
On a more pragmatic issue, the imprisonment of politicians and the international extradition order of the Supreme Court judge against the fugitive representatives indicted ${ }^{51}$ point to the various scales at which the different agents are judicializing the process. Generally speaking, the strategy of the pro-independence lawyers, politicians, and media has been to (1) point to the politicization and non-independence of the judicial Spanish system, (2) claim that those imprisoned are charged for their ideological position and hence are "political prisoners," (3) define the former situations as a political involution of Spanish democracy, and (4) appeal to Europe and its democratic juridical system as a superior legal order (whether expressed in concrete states such as Belgium or Germany, in the Court of Justice of the EU, or the International Court of Justice).

\section{Legality and Legitimacy: the Politics of the "People"}

An important argument for those supporting independence is that legitimacy trumps legality. Indeed, it is impossible to legally declare independence within the present constitutional order; thus, the force of right needs to be based on the legitimacy of popular will. What kind of majority expresses the popular will? What kind of minority will be left to grieve the violation of its popular will? These are the issues that are being debated through media discourse and mobilizations in presentday Catalonia. But first, a word of caution: although massive demonstrations have become the norm in the nationalist debate, what is less obvious is that these demonstrations have completely displaced, silenced, and transmogrified the massive protests against austerity that took place from 2011 to 2013 in Catalonia as in the rest of Spain. ${ }^{52}$ The

51. As of August 2018, the extradition order has been revoked. In July 2018 the High Court of the region of Schleswig-Holstein in Germany ruled that the former President of the Catalan government could only be extradited for misappropriation of public funds but not for rebellion or sedition. As a result, the Spanish judge did not accept this ruling and declared the extradition inadmissible. See María-Paz López, Alemania acepta extraditar a Puigdemont sólo por malversación y no por rebelión, LA VANGUARDIA, https://www.lavanguardia.com/politica/20180712/45850607483/puigdemont-extradicionalemania-malversacion.html (last updated July 13, 2018).

52. Very recently, important protests against pension cuts all over Spain have also been followed in Catalonia. Interestingly, these protests have the strongest participation in industrial and post-industrial regions of Spain. See Público/Efe Miles de jubilados se concentran en toda España para reclamar unas pensiones dignas Público, PúBLICO (Feb. 22, 2018 12:24 PM) https://www.publico.es/economia/miles-jubilados-concentran-espanareclamar.html; Erlantz Gude Una histórica marea por unas pensiones "dignas" pone en aprietos al Gobierno, EL CORREO (Mar. 17, 2018 4:53 PM) https://www.elcorreo.com/economia/pensiones/marea-jubilados-echa-20180317165245nt.html\#. 
argument that the fiscal deficit with the state is responsible for the cuts to public services that the autonomous government implemented implicitly presupposes (and sometimes explicitly exposes) that the end of austerity will come with an independent Catalan state. If we look at the map of revenue per capita and the incidence of independent votes in Catalonia, we get an image similar to that of the Brexit voters in the UK: lower revenue areas (in this case mostly rural agricultural ones), which have been extremely dependent on redistributive transfers directly from the Catalan government for years, are the strongest supporters, although often the funds distributed come from the EU via state and regional governments (such as Feder funds). ${ }^{53}$

What is the evidence for a majority? It is the evidence of numbers first. But what numbers count is debatable. For example, in the last two plebiscitary elections, the discrepancy between the majority of seats in Parliament for secessionist parties and the majority of votes for nonsecessionist parties renders the claim of a majority vulnerable. ${ }^{54}$ During the two referendums (November 9, 2014 and October 1, 2017), the resounding majority in favor of independence (80.8 percent and 90.2 percent) came at the expense of a low turnout, respectively around 36.6 percent and 43 percent. ${ }^{55}$

Likewise, the massive demonstrations of September 11, always described as gathering around one million participants, ${ }^{56}$ are arguably a

53. See Raúl Sánchez, Belén Picazo \& Yuly Jara, La demografía del 21D, así votó cada grupo social, EL DIARIO.ES (Dec. 22, 2017, 7:20 AM), https://www.eldiario.es/politica/Resultados-mapa-voto-independentista-

Catalunya_0_720578676.html; Raúl Sánchez et al., La Catalunya que nos deja el 21D. Un análisis de los resultados, EL DIARIO.ES, https://elecciones.eldiario.es/ analisis21D/?_ga=2.251450950.1918933085.1535293046-530758308.1508688262 (last visited Aug. 18, 2018) (displaying a sociological analysis of the votes).

54. See Miquel Noguer, Los independentistas ganan las elecciones y pierden su plebiscito, EL PAÍS (Sept. 28, 2015, 4:10 PM), https:/elpais.com/ccaa/2015/ 09/27/catalunya/1443387513_045607.html (discussing the election of September 27, 2015); $21 D$ Elecciones Catalanas, EL PAÍs, https://elpais.com/tag/elecciones_catalanas/a/ (last visited Aug. 18, 2018) (discussing the election of December 21, 2017).

55. See Mario Ríos, El 9-N: Historia de dos países, El DiARIO.Es (Nov. 12, 2014, 8:51 AM), https://www.eldiario.es/catalunya/Historia-paises_0_323717686.html (discussing the referendum of November 9, 2014); $9 N$ 2014, GEnERALitAT DE CATAlunya, http://www.participa2014.cat/resultats/dades/ca/escr-tot.html; El Govern anuncia una participación de 2,2 millones de personas, con un 90\% para el 'sí, EL DIARIO.ES (Oct. 2, 2017, 12:48 AM), https://www.eldiario.es/catalunya/Govern-anuncia-participacionmillones-personas_0_692930704.html (discussing the referendum of October 1, 2017).

56. Depending on the political orientation of the media and of the institutions calculating participation, the numbers vary from 500,000 to over a million. See Diada 2018: este gráfico es un intento de representar objetivamente la evolución de asistentes, EUROPA PRESS, http://www.europapress.es/nacional/noticia-diada-2017-grafico-intento- 
popular expression of support, but they are far from representing all the Catalan population or even a majority. They are nevertheless put forward by supporters of independence and by international media ${ }^{57}$ as being a clear expression of the will of a majority of the "Catalan people." The metonym is often treated as a fact, as evidence in the struggle for legitimacy: Catalan people (as a whole) support independence and (as a whole) hold nationalistic grievances against the Spanish state. Although this position is repeated in discourses and the media, in reality, the leaders of the national transition process in the strategic document "\#EnfoCATS" (ca. 2017) ${ }^{58}$ are clearly aware that they do not have a social majority support, and one of their main objectives is precisely to "widen the social base." In this document,the population of Catalonia is ranked on a continuum according to their degree of conviction for the independence cause as: (1) "hyperventilated 59 conviction," (2) "historic conviction," (3) "recent but frail conviction," (4) "fraternal regenerationists, ${ }^{60}$ " (5) "uncertain," (6) "presently impervious," and (7) "convinced of NO." Each of these categories will require a specific approach to convince them of the benefits of secession. Hence, the "evidence of numbers" of actual popular support is interpreted in different ways by the strategists based on whether they are performing the metonym of a majority for the media and the general public (a "People") or whether they are analyzing the necessary tactics to gain a real social majority.

The metonym of the Catalan people has an additional consequence: the corporatist expression of a homogenous "nation" welded in a transcendent identity recognition claim. Massive demonstrations and the ubiquity of symbols such as the Catalan independence starred flag (estellada) $^{61}$ hide a complex reality where identities are often tied to histories of migration and class differentiation. Supporters of independence describe the humiliation they have suffered historically at

representar-objetivamente-evolucion-asistentes-20170909085120.html (last updated Sept. 11, 2018).

57. The International media's sources have been mostly fed by various news agencies subsidized by the Catalan government, such as Diplocat, Catalan News Agency, Vilaweb, and TV3. Reporters have been seduced by the righteousness and democratic claims of independence supporters (highlighting alleged repression by and undemocratic aspects of the Spanish state).

58. \#EnfoCATs: llegiu el document que ha deixat Junqueras a la presó, ELPERIODICO (Dec. 6, 2017, 06:40 PM), https://www.elperiodico.cat/ca/politica/20171205/enfocatsdocument-junqueras-preso-6475171.

59. Overexcited

60. Supporters of a new constitutional structure and often partisans of an agreed legal referendum.

61. The legal Catalan flag does not have a star. 
the hands of Spanish governments (or in another metonym "Madrid"): their fight for dignity is tied to achieving sovereignty. From a different experience, the migrants that came to Catalonia in the 1960s from the poorer regions of Spain have ambivalent feelings, as they recall the humiliation they suffered as second-class citizens (xarnegos), but they are grateful for the economic opportunities of social mobility that the local industry provided them. The second generation, born and raised in Catalonia and educated in Catalan speaking public schools, often feels they have a dual identity: they are Catalan Spaniards. If we look at a map of voters supporting what the media call "unionist" parties, ${ }^{62}$ the coincidence with the old immigrant working class belt is striking. Sadly, in the present conjuncture, these voters who used to favor social democratic or socialist parties (mostly as a result of a past of militant trade unionism) are now voting on the grounds of identity positioning, that is, mostly against secession. This has displaced their vote toward a neoliberal right wing party Ciudadanos (Citizens) that was formed to counter the rise of Catalan nationalism and defend the Spanish language in 2006. ${ }^{63}$ Many of these voters are described by some Catalan nationalists as "fascist" supporters of the extreme right, the Spanish government, or the allegedly undemocratic judicial actions of the state. For most of those targeted, this characterization is very far from their actual social and political genealogies, as many arrived in Catalonia because of their socialist or anarchist past and the systematic repression and exploitation they suffered from police and landowners after the SCW, ${ }^{64}$ although the nationalist antagonism has shifted many voters away from the Catalan Socialist party (PSC) to the neoliberal Spanish nationalist party Ciudadanos in the recent elections. So called unionists have been silent until recently, surrendering the floor of public space mobilizations to independence supporters. To show the strength of their numbers, however, they also organized several massive demonstrations in October 2017 to counter totalizing narratives about Catalan "people."65

62. Parties that do not support independence.

63. See Raúl Sánchez, Así se destiñó de rojo a naranja el cinturón de Barcelona, clave para el 21D, EL DIARIO.ES (Dec. 16, 2017, 7:32 PM), https:/www.eldiario.es/ politica/destino-naranja-cinturon-rojo-Barcelona_0_718479182.html.

64. See generally GEORge A. COLliER, Socialists OF RURAL ANDAlusia: UNACKNOWLEDGED REVOLUTIONARIES OF THE SECOND REPUBLIC (1987) (an anthropological and historical account of the overall movement of socialists in Andalusia and their migration as a result of repression after the SCW).

65. See Cientos de miles de personas reclaman en Barcelona la unidad de España, EL DIARIO.ES (Oct. 8, 2017, 11:22 AM), https://www.eldiario.es/politica/Miles-personasreclaman-Barcelona-Espana_0_695030592.html; Miles de personas se manifiestan en Barcelona en defensa de la unidad de España, EL DiARIO.ES (Oct. 29, 2017, 12:03 PM), 
In this context, the battle for legitimacy through numbers is linked to the tacit evidence of different experiences that have historically produced complex identities and many declensions of the Catalan people. As evidentiary proof of a unitary nationalist spirit, however, numbers are moralized and citizens ranked into "good" and "bad," pushing towards corporatist and exclusionary identities in Catalonia and in Spain.

\section{Memory, Performance and Mobilization}

Evidence struggles are also fought in terms of symbolic performances. Those most frequently used by independence supporters refer to past historical memories of 1714, the Spanish Civil War (SCW), political exile, and political repression during the dictatorship and Transition years. Less frequent reference is made to major international figures of national liberation (like Ghandi or Mandela). These references seek to create emotional connections that will reinforce legitimacy by providing evidence of a long history of human and political rights violations against Catalonia. They do not go uncontested. A common rejoinder points to the incommensurability of the comparisons or even to intentional misrepresentation of the past. In the juridical arena, the symbolic connections are also present as both the Llibre Blanc sobre la Transicio Nacional de Catalunya (White Book on the National Transition of Catalonia) and the Supreme Court's rebellion indictment show. 66

The SCW, the dictatorship, and the Transition are still very present memories in Spain. The fact that the Transition was built on a general amnesty and a pact of silence about the previous regime's atrocities and that the Law of Historical Memory (2007) was abandoned as soon as the conservative Popular Party (PP) came into power in 2012 makes the past still present in today's politics. The Transition period was

https://www.eldiario.es/catalunya/barcelona/Partidarios-Espana-manifestan-Barcelonalegalidad_0_702379795.html.

66. The former gives a long list of historical grievances; the latter mentions how, in order to inflame the public against a police search in the Catalan department of economy, the defendant cried "No pasarán!”, a clear reference to the communist leader Pasionaria's cry in the defense of Madrid against the rebel troops of Franco during the SCW. With this, the judge makes a direct (and unwarranted) connection between the defendant's actions and the SCW violence, and between the defendant and communist ideology (arguably an evidently "bad" ideology). See Auto de 21 de marzo de 2018 can be found here http://www.poderjudicial.es/cgpj/es/Poder-Judicial/Tribunal-Supremo/NoticiasJudiciales/El-juez-Pablo-Llarena-procesa-por-un-delito-de-rebelion-a-13-de-losinvestigados-en-la-causa-por-el-proceso-secesionista-de-Cataluna (last visited Dec.13, 2018) (Spain). 
simultaneously a continuation of the Francoist regime, a recuperation of the political status quo ante of the Republic, and an attempt to become a modern democratic European nation. This resulted in a parliamentary democratic system albeit within a constitutional monarchy following the dynastic head of state design re-instituted by Franco. The past is indeed present in everyday politics as stories about families' political positioning during the war, their politics during the dictatorship, and the struggles of the transition are still references that divide the political moralities of people. Likewise, reference to this recent history is publicly used to assess the trustworthiness of politicians, often tracing it to the political positions of their ancestors. Hence, using symbolic connections to the past is an extremely useful way to legitimate or delegitimate actions or individuals. It also contributes to positioning present actions within an emotionally charged political lineage.

An example of this is the construction of the former president of the Generalitat's escape as an "exile", the "legitimate government in exile," and his followers' insistence that he is still the legitimate president. This created a parallel between the application of Article 155 of the Constitution dissolving the Catalan Parliament after the unilateral declaration of independence and the flight of the Republican Generalitat in 1939 from the Francoist troops. The designation of the "Free Space of Brussels" as the seat of the legitimate Catalan government, the creation of the Council of the Republic, and the creation of an Assembly of Representatives that would operate in parallel to an executive legal Catalan government in Catalonia (February 2018), is a creative reference to the parallel government of the Generalitat in exile during the dictatorship. This historical reference legitimates the position of the deposed government and its actions and creates a new kind of evidence strengthened by the moral connotations of the past. At the same time, it attempts to make this dual structure legal through changes to the law of the Catalan government and presidency that would be approved by the Catalan Parliament (and very certainly declared unconstitutional by the CC). ${ }^{67}$

On a different front, performances, such as the massive September 11 demonstrations, are evidence of the peaceful character of the Catalan mobilizations for independence. They express the democratic aspect of the movement and its non-violence as the "smiling revolution." Violence is a feature of the state and in particular of a Spanish right wing PP government whose members are in the lineage of the dictatorship. ${ }^{68}$

67. See LEY 13/2008 DE LA PRESIDENCIA DE LA GENERALIDAD Y DEL GoBIERNO.

68. Actually, violence is also a feature of the Catalan government as was obvious during the repression of the 15-M Indignados social movement in Barcelona. See AMAT supra note 36 , at 68-69. 
This image of the demos peacefully making a legitimate claim in the street, claiming the public space of the nation, and embodying "freedom of expression" is a message to the world: there is only one legitimate demos, and we are it. There is no doubt that supporters of independence are extremely successful in the performative aspect of the evidence struggle over legitimacy, especially in its international projection. Meanwhile, the state hides behind the judicialization of the conflict although upholding legitimacy in the face of continuous performances of historical grievances and of the will of the "Catalan people" remains a challenge, at least in Catalonia and the international arena.

One of these symbolic performances took place during the Easter holiday, in March-April 2018. On March 30, groups of independence supporters planted yellow crosses in several beaches in the province of Girona. The crosses had words such as "freedom," "democracy," "republic," "equality," "solidarity," and "justice," symbolizing the death of liberty and other political virtues. ${ }^{69}$ The Committees in Defense of the Republic (CDR), a civil society group that has organized most of the symbolic performances such as the tying of yellow ribbons all over Catalonia asking for the freeing of "political prisoners," were also responsible for the planting of crosses. In this action, they included the beach of Argélès-sur-mer in France, an area that Catalan nationalist call Northern Catalonia, and where Spanish Civil War refugees were held in a concentration camp in February 1939 when they crossed the border fleeing Franco's troops. The action was clearly meant to recall this past event and to make parallels between repression and fascism then, and its alleged repetition in the present, forcing the flight to exile and imprisoning those that fought for the Catalan Republic and for national freedom. However, this was not well received by people whose kin had crossed to France and ended in Argélès in 1939. In a tweet, Patricia, an ordinary Catalan citizen, comments this action as follows: "[m]y mother's family, socialist miners from Andalusia, ended at Argélès in the winter of 1939. Today, those that consider us inferior and call us, the grand-children [of those socialist miners], colonial settlers ${ }^{70}$ use that

69. See Pere Vilanova, De primaveras y cruces, EL PAís (Apr. 6, 2018, 6:28 PM), https://elpais.com/ccaa/2018/04/05/catalunya/1522942158_526982.html; Los CDR plantan cruces amarillas en las playas de Port de la Selva, Cadaqués y Argelers, EuROPA PRESS (Mar. 31, 2018, 5:47 PM), http://www.europapress.es/catalunya/noticia-cdr-plantan-crucesamarillas-playas-port-selva-cadaques-argelers-20180331150439.html.

70. An accusation thrown by some radical Catalan nationalists at the immigrants from Andalusia is that of having been settlers catering to the Francoist intent to reduce Catalan identity through the massive migration from Southern Spain. See Manifest del Grup Koiné a favor del català com a única llengua oficial, EL PERIóDICO (Apr. 1, 2016 / Feb. 16, 2018 2:32 PM) https://www.elperiodico.cat/ca/politica/20160401/grup-koinemanifest-catala-unica-llengua-oficial-5018986 ; Manuel Cuyàs Colonització involuntària, 
suffering. They are shameless." 71

Nevertheless, the Catalan "unionists" are at pains to find a collective voice that would appeal to a different kind of legitimacy (and this may be impossible precisely because of multiple and violently conflictive past political genealogies among them during the SCW and the Transition). Recently, however, some have countered with a political performance: the claim for a new nation, Tabarnia, that would comprise the provinces of Tarragona and Barcelona - the richest and most industrialized areas which sustain a fiscal deficit with the rest of Catalonia. Legitimacy for this claim rests on mimicking some of the arguments put forward by sovereignty supporters, but it also refers to a memory of repression. This imaginary nation is a creation of the theatre director of Els Joglars, Albert Boadella, whose play La Torna (1977) was considered an offense to the military during the Transition and led him to be indicted in a military trial. He was imprisoned and escaped to Belgium, re-entered Spain and was arrested, and finally was pardoned. As the first repressive judicial act against freedom of speech of the Transition, this event triggered massive mobilizations in defense of "freedom of expression." The poster and logo that were created then in support of the right to freely express ideas and as a sign that democracy was not yet accomplished have been plagiarized by Catalan nationalists as the main image in support of the imprisoned Catalan politicians and of ideological freedom of speech. Boadella, however, is now a staunch critic of Catalan nationalism who has veered to the right since his earlier days, and has (1) vindicated the different context of his original critique to the dictatorship, and (2) responded with the creative performance of a new secessionist nation within Catalonia: Tabarnia.

\section{CONCLUSION: SHIFTS IN STRUGGLE}

Different kinds of evidence are used to argue, justify, and mobilize political action, but the evidence is about truth. Direct evidence, circumstantial evidence, and testimonies about present and past injustice are all contending in the arena of factual truth-making and foreclosing the possibility of pluralist interpretations up for public debate. ${ }^{72}$ While some render the Constitution and its definition of Spain as the only sovereign nation a dogma of faith, others present the nature of the Catalan "people" as an essential truth. In the struggle, truth,

EL Punt AvUi (Apr. 7, 2016 2:00 AM) http://www.elpuntavui.cat/opinio/article/8articles/956085-colonitzacio-involuntaria.html.

71. Patricia (@patgato), TwiTTER (Mar. 31, 2018, 11:30 AM), https://twitter.com/patgato/status/980105167348621312.

72. See Hannah Arendt, Truth and Politics, The New Yorker, Feb. 25, 1967, at 49. 
opinion, and ideology, become equivalent and democratic pluralism unviable. The struggle is about making factual truth unassailable through evidence, it is not a struggle about contestable interpretation and opposing projects. Thus, it is about the capture of politics by truthmaking struggles that attempt to render a particular political project incontestably self-evident.

While there is plenty of evidence that illegal actions were committed in the fall of 2017, the political project that backed them might be legitimate, and evidence is brought forth by its supporters. The Catalan conflict is a political one that cannot be resolved judicially, and the kind of factual evidence that the judge proposes (documents proving intent to secede and actions against the law) operates among other forms of evidence, mostly historical, symbolic, and performative. Ethnographically, we observe a complex evidence struggle that attempts to legitimate political action. Mobilization of support for the different political objectives rests on an entanglement of legal and emotional, dystopian and utopian, and past and present modes of reason. But cui prodest?

The fight between nationalisms (Catalan and Spanish) is producing a shifting understanding of inequalities, namely a shift from social to territorial, and identity arguments of differentiation. The confrontation is against the external offender defined in essentialist terms (such as "Madrid steals from us," "we are supporting the lazy Andalusians," or "those greedy Catalans"). This nationalist strategy hides the long-term alliance between the conservative elites in both regions and their joint support of neoliberal policies, large corporations, and financial capital. Presently, competition between local spaces as foreign investment sites has become increasingly central in global capitalism and has produced tensions around re-scaling control over regulatory frameworks. The question is: who will benefit from the re-scaling process in Catalonia? Local political elites and some powerful economic actors hope that their ability to control local resources (in particular taxation) would benefit them. Their ability to shape extra-local regulatory regimes (such as the European Union or bilateral agreements) would also increase due to direct negotiation with international regulatory bodies, and hence their power would be unmediated. Yet the real value of national sovereignty (even democracy) in a global economy regulated by unelected transnational institutions, such as the IMF, WB, or ECB is questionable, as the Greek case exemplified in 2015. We might be witnessing the emergence of a post-global world, however, where barriers to circulation (of goods and people) expand, albeit selectively. In this context, nationalism and borders may appear as a protection that would provide "citizenship rents." This was the promise of Brexit and of 
many populist nationalist parties in Europe, such as the Lega (League) in Italy. In this uncertain situation after a devolutionary moment in the 1980s, the nation-state structure (and the supra-national EU structure with it) seems to be entering a phase of re-centralization that is countered by regional power holders.

It is difficult to know how this would affect ordinary people's livelihoods. In Catalonia, some of the more vocal secessionists in the left (the anti-capitalist CUP) say that the downscaling of regulation from the Spanish to the Catalan state would enable the expansion of the welfare state and would give more leverage to popular mobilization, which would widen the scope for participatory democracy.

For the time being, the rise of nationalism, populism, and sovereignty struggles in a post-global world raises frightening memories of the past in Europe. As in the past, the evidence used to mobilize people is multiple, often countering legality on the grounds of legitimate grievances and performing legitimacy in public spaces and by reference to the past. At the supra- and sub-national levels, the rule of law and the pluralist process of liberal democratic deliberation is challenged by concrete agents that use symbolic and performative evidence to get political leverage and accomplish change. Downscaling the state might be a response to the territorial dislocations brought about by neoliberal globalization, but nationalist, corporatist, and totalizing understandings of the issues at stake might just shift the representation of the conflict instead of dealing with its causes. 